\title{
MAFHŪM AL UMMAH Fİ AL QURĀN AL KARĪM
}

\author{
مفهوم الأمة في القرآن الكريم \\ Ubaidillah \\ UIN Sunan Gunung Djati Bandung, ubaidillahadi@gmail.com
}

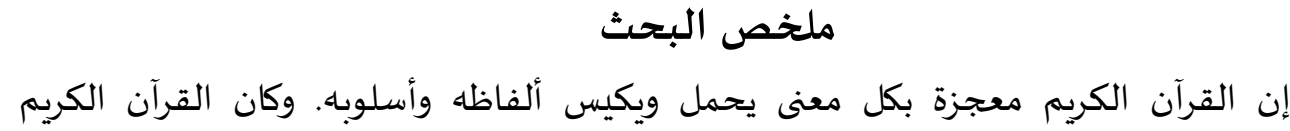
معجزته من ناحية اللغة وكانت لغته لغة عربية وللغة ثروة المفردات وفي ضمنها الألفاظ المشتراكة وهي لفظ الذي له معنا كثيرة. وفى القرآن كثير من ألفاظ المشترك منها لفظ (الأمة). لفظ (الأمة) في القرآن الكريم وصل إلى نتائج منها: () أن المعاني المعجمية للفظ (الأمة) فبمعنى أسوة وقدوة. ومعناه العام لا يخلو من معنى الجماعة من الناس. r) أن المعاني السياقية للفظ (الأمة) فبمعنى الوقت، والإمام،

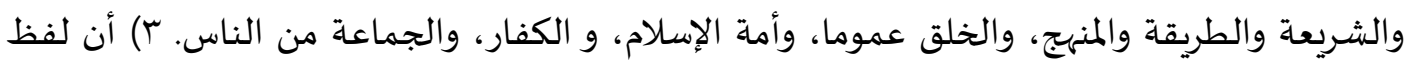

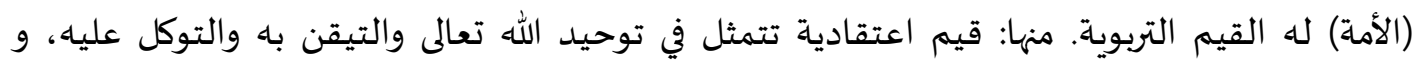
طاعة الله بحسن الطاعة. وقيم خلقية تتمثل في أهمية انتهاز واستغلال الأوقات والفرصية،وكذلك توحيك الإخلاص. وقيم عملية مثل التسامح والعدل والأمانة والجرأة والتعاون والإيثار والقوة. وهي تتمثل في أداء حقوق الانسان بالعدل. الكلمات المفتاحية: الأمة، الدلالة، المشترك، المبل، القيم التربوية.

\section{Abstrak}

Al-Qur'an merupakan mukjizat dalam setiap kata dan gaya bahasa yang terdapat didalamnya. Salah satu mukjizat yang terkandung didalam Al-Qur'an adalah dari segi kebahasaan, yaitu bahasa Arab yang kaya akan kosa kata serta terdapat banyak kalimat-kalimat yang memiliki banyak makna atau biasa dikenal dengan musytarak. Dalam Al-Qur'an sendiri terdapat banyak lafadz musytarak diantaranya adalah lafadz Al-Ummah. Hasil penelitian tentang lafadz Al-Ummah didalam Al-Qur'an menunjukan beberapa hal, diantaranya : 1) Makna leksikal dari lafadz Al-Ummah adalah contoh dan panutan serta secara umum lafadz Al-Ummah bermakna kelompok orang. 2) Makna kontekstual dari kata Al-Ummah adalah waktu, imam, ajaran dan pedoman hidup, makhluk secara umum, umat Islam, orang-orang kafir, dan sekelompok orang. 3) lafadz Al-Ummah memiliki nilai-nilai pendidikan di antaranya : Nilai-nilai keyakinan 
Ta'Cim al-'Arabiyyah : Jumal Pendidikan Bahasa Arab dan Kebahasaaraban, 3 (2), 2019

yang termanifestasikan dengan meyakini akan keesaan Allah SWT serta bertawakal kepada-Nya. Nilai-nilai moral yang termanifestasikan dengan pentingnya memanfaatkan dan menggunakan waktu serta adanya ketulusan hati. Nilai-nilai praktis seperti toleransi, keadilan, kejujuran, keberanian, kerja sama, altruisme, dan kekuasaan.

Kata kunci: al-ummah, semantik, musytarak, nilai-nilai pendidikan.

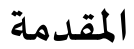

القرآن الكريم هو كلام الله تعالى المعجز، الموحى باه إلى النّبي محمد عليه المباء الصّّلاة

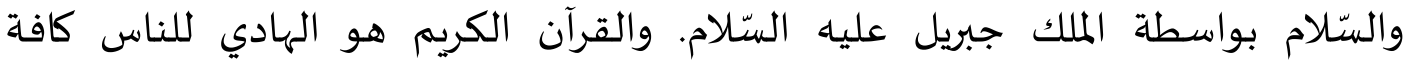

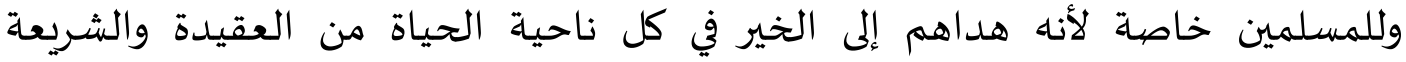

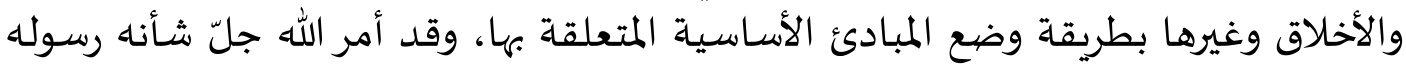

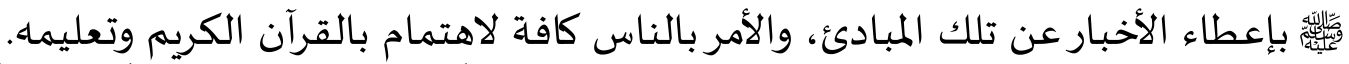

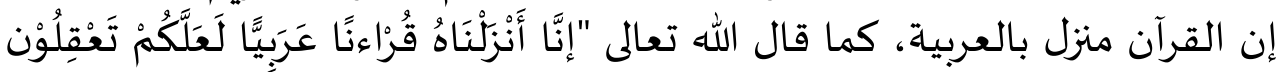

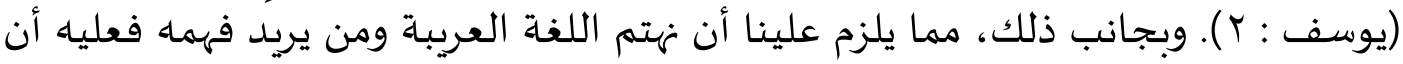

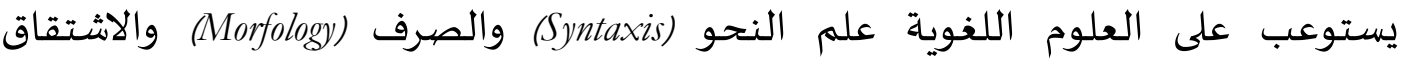

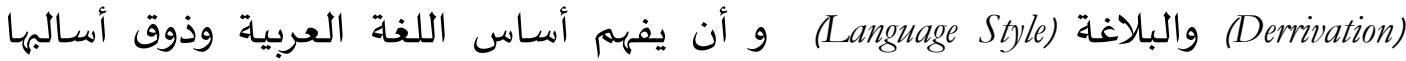

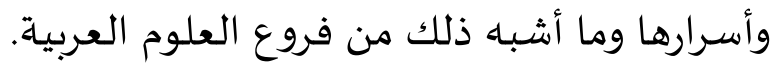

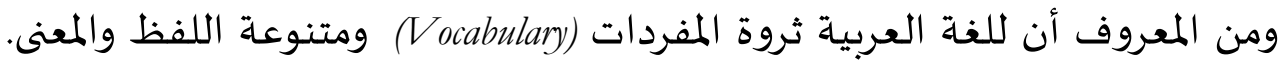

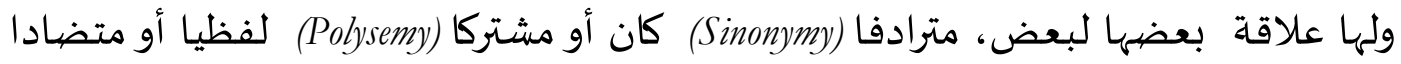

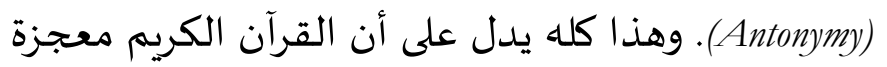

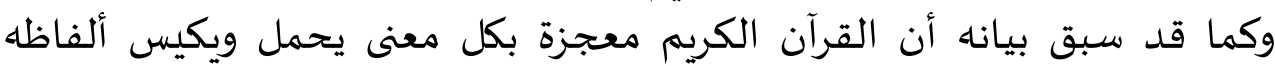

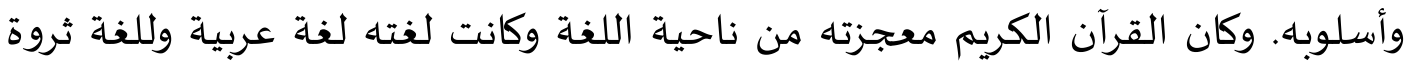

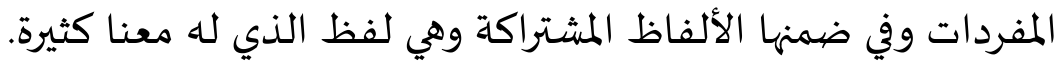

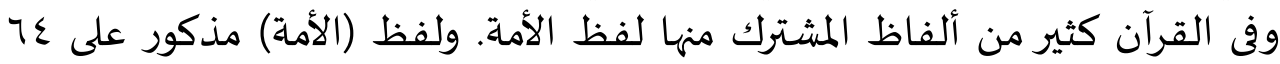

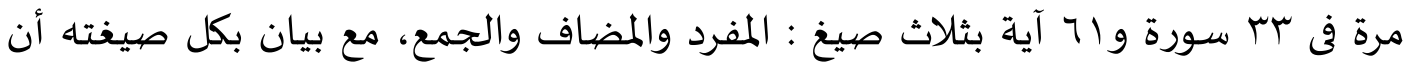

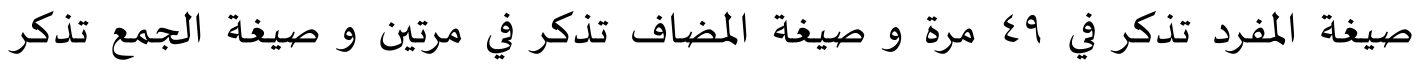

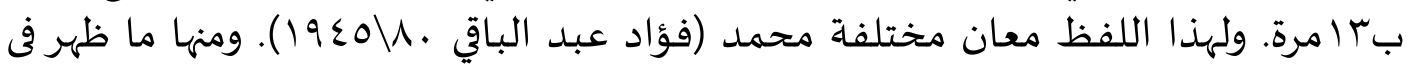

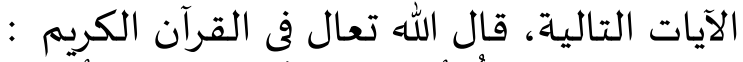

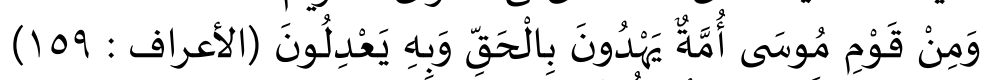

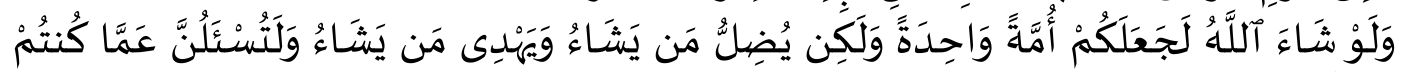

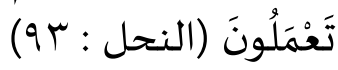

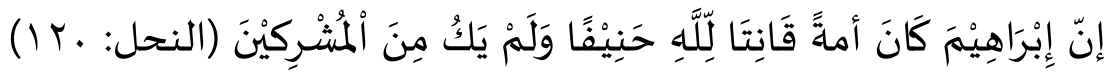

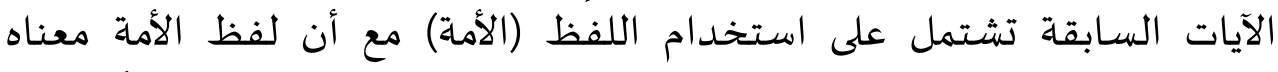

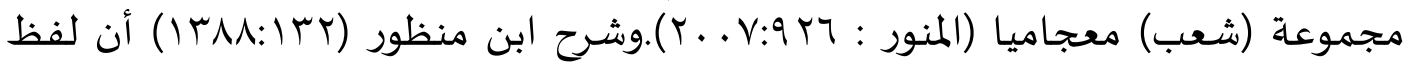


Ta'lim al-'Arabiyyah : Jurnal Pendidikan Bahasa Arab dan Kebahasaaraban, 3 (2), 2019

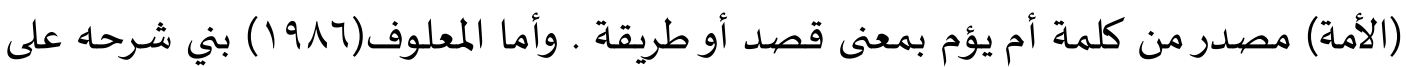

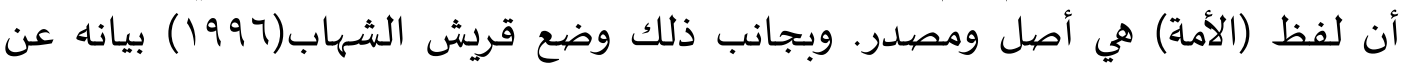

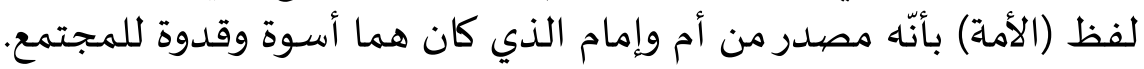

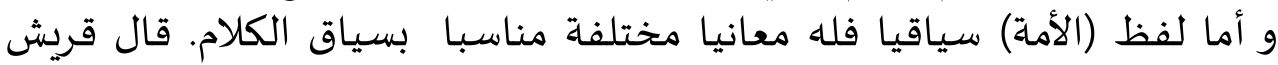

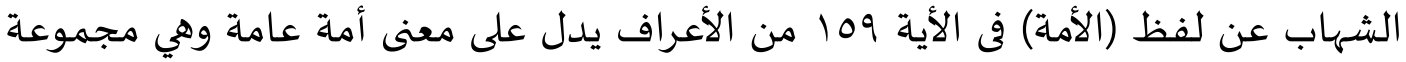

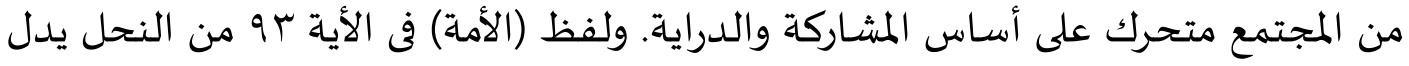

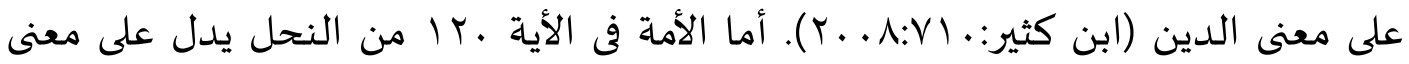

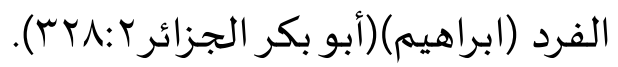

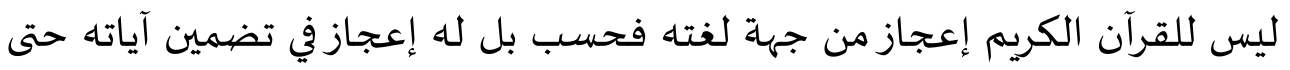

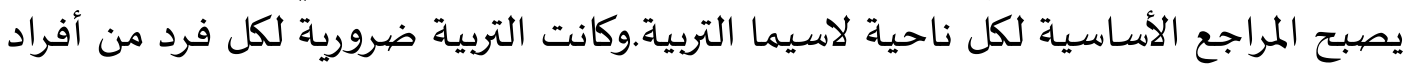

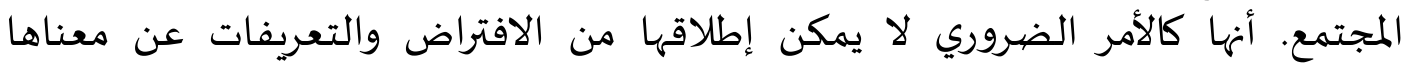

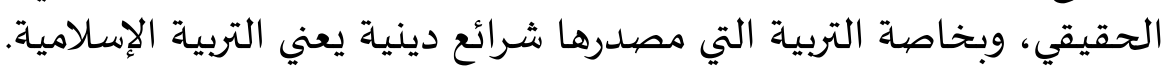

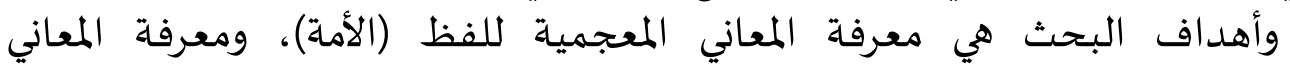

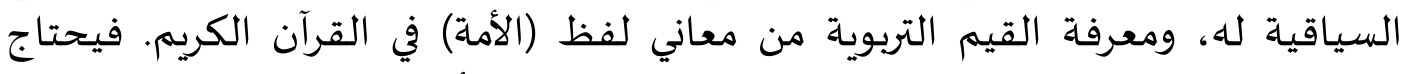

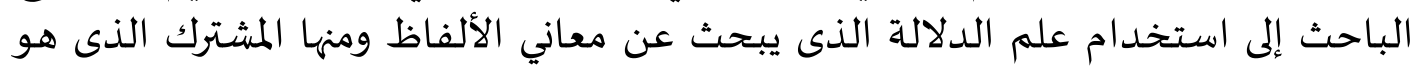

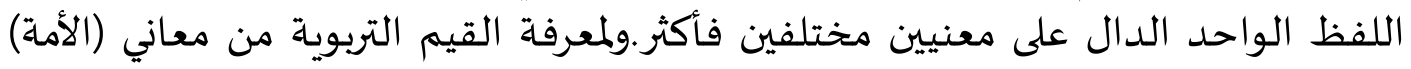
يعتمد الباحث على علم التربية الإسلامية.

\section{البحث

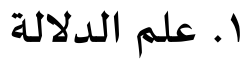

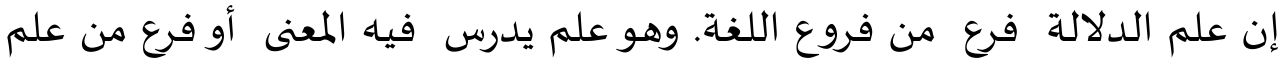

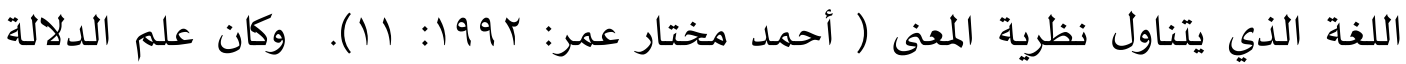

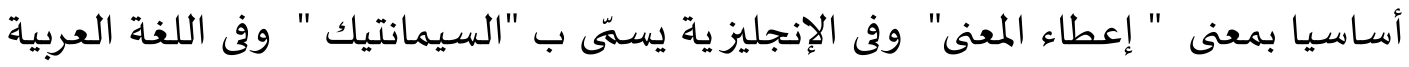

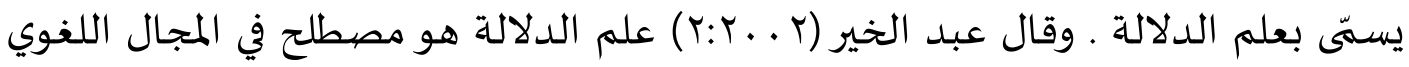

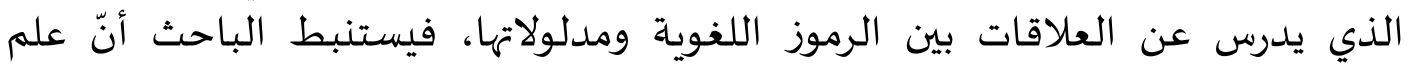

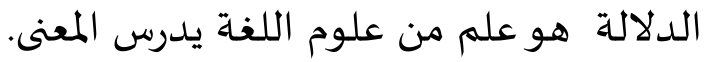

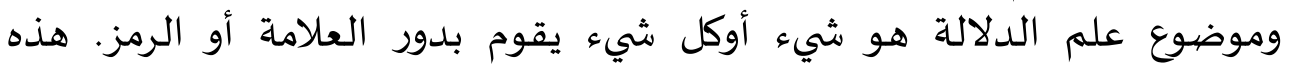

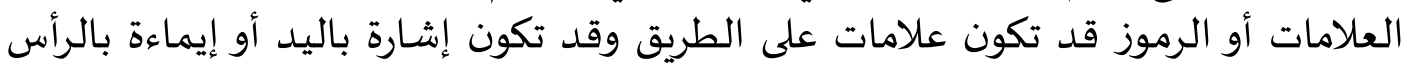

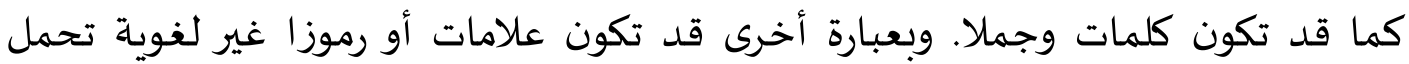

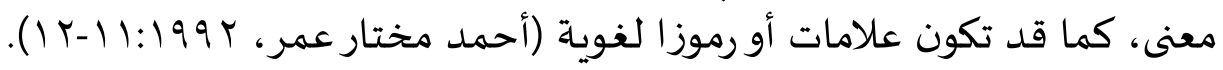

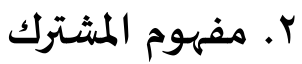


Ta'Cim al-'Arabiyyah : Jumal Pendidikan Bahasa Arab dan Kebahasaaraban, 3 (2), 2019

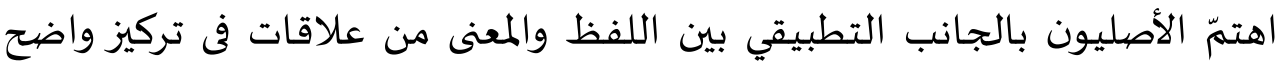

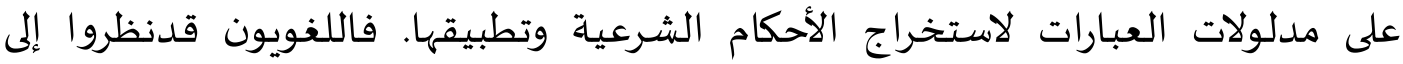

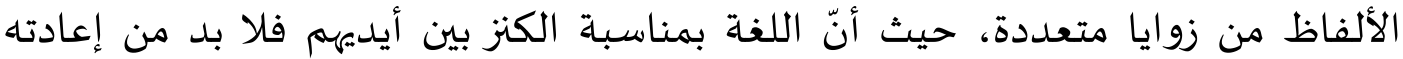

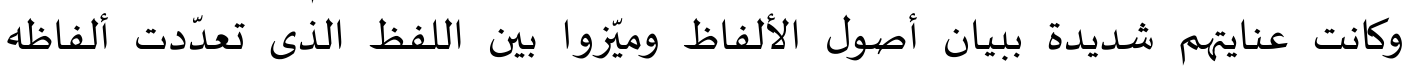

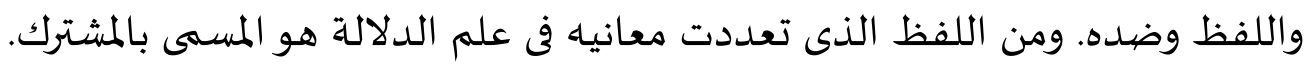

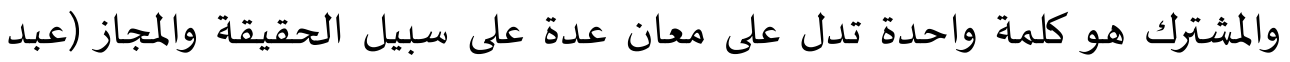

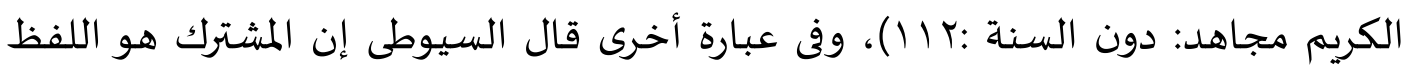

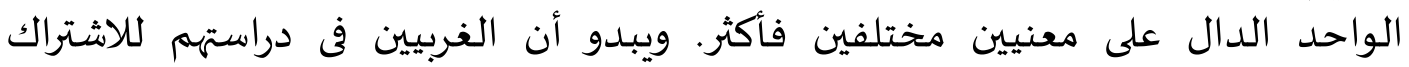

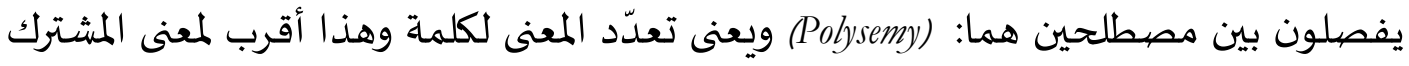

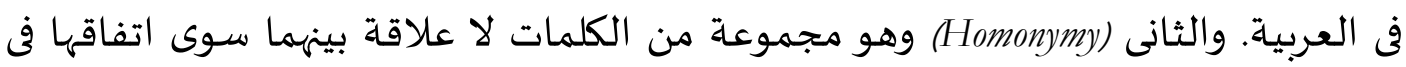

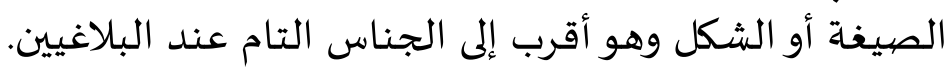

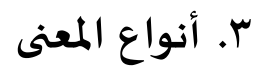

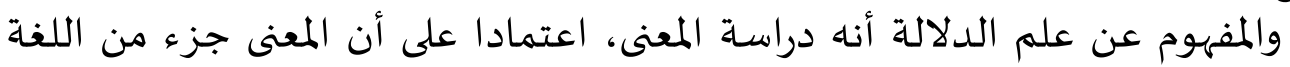

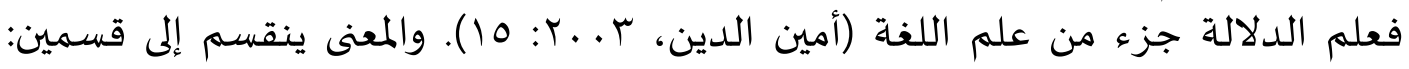

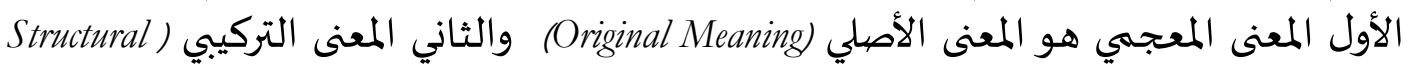

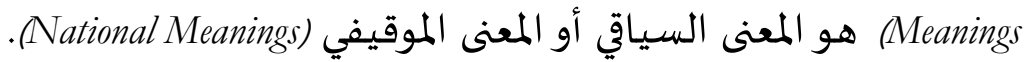

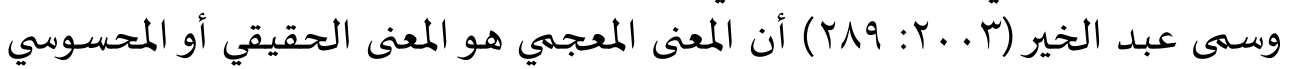

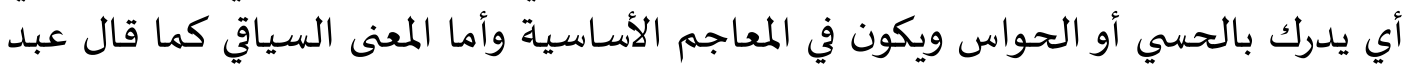

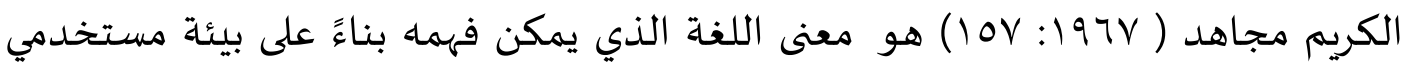

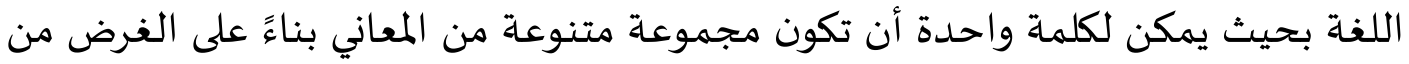
السماعة.

ع. قيم التربية الإسلامية

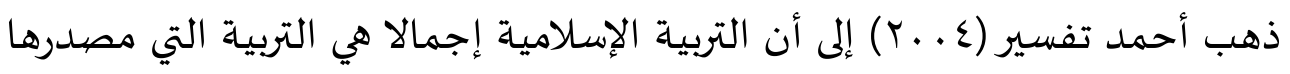

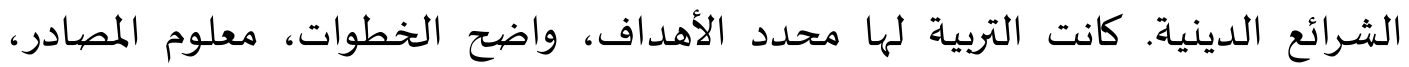

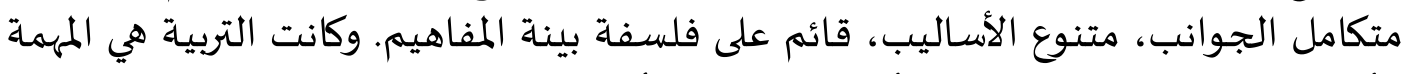

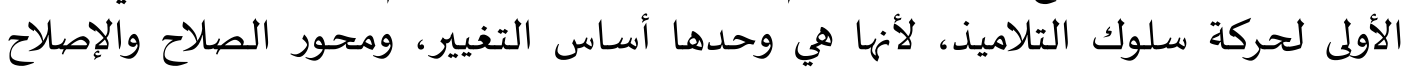

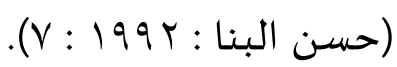

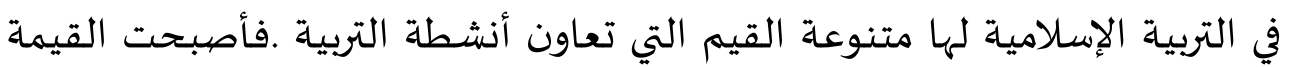

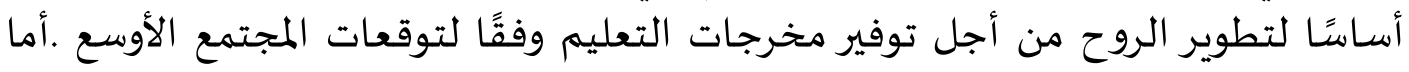

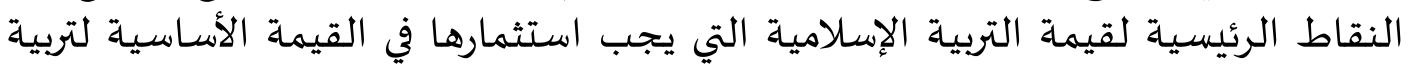
الأولاد وتعليمهم تشتمل على المكوّنات التعليمية التي تنقسم إلى خمسـة أقسام منها الأستاذ التهاذ 
Ta'Cim al-'Arabiyyah : Jurnal Pendidikan Bahasa Arab dan Kebahasaaraban, 3 (2), 2019

أي المعلّم والتلاميذ والمواد والطريقة التعليمية أي وسائل التعليم والأغراض والتقويم

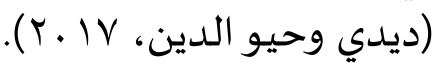

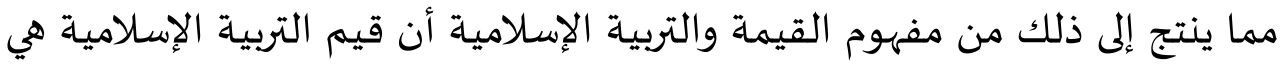

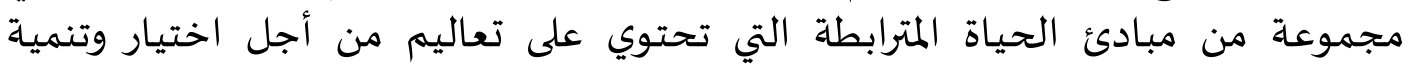

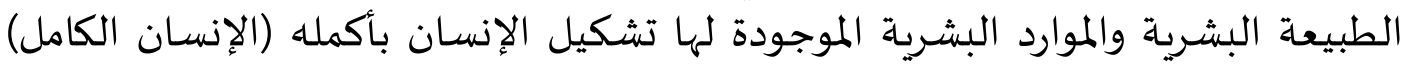
وفقا للمعايير أو التعاليم الإسلامية.

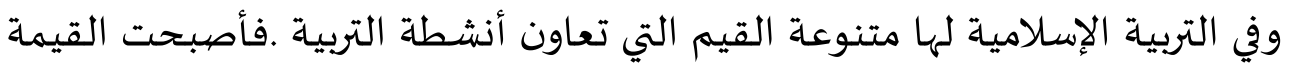

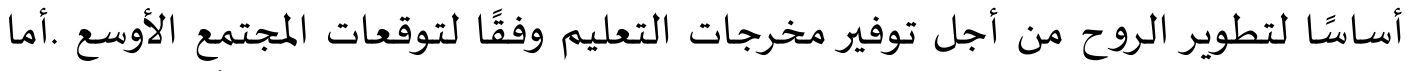

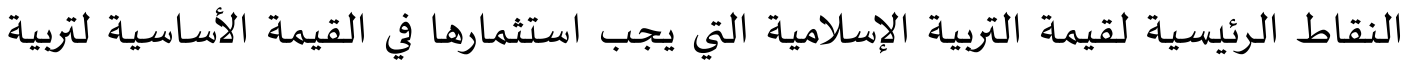

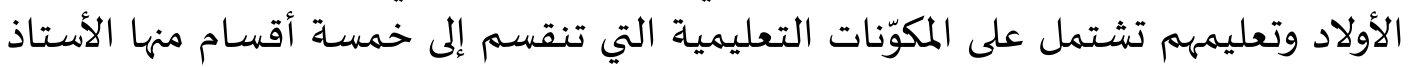

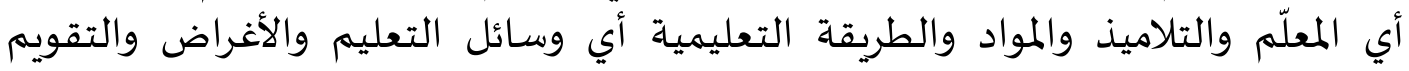

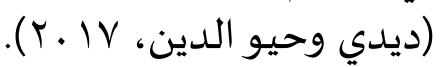

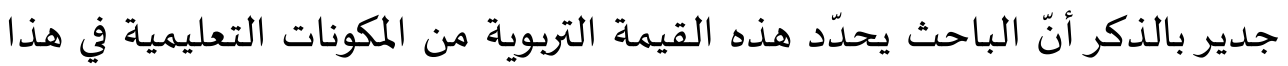

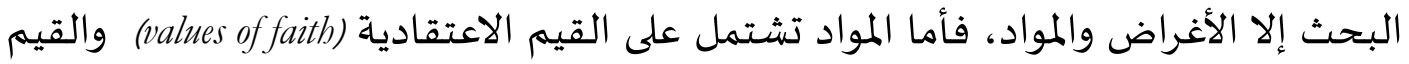

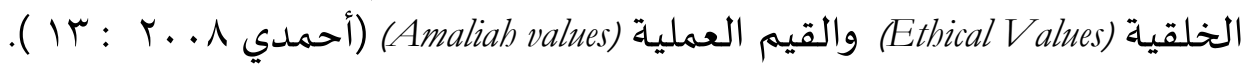

ه. الأمة في القرآن الكريم ومعناها المعجمية والسياقية

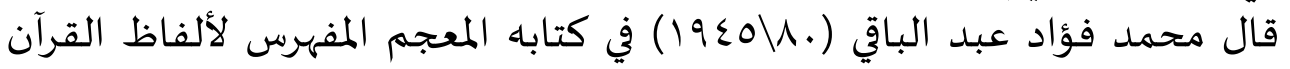

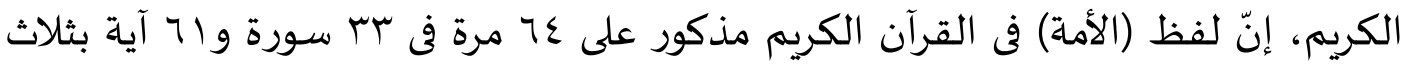

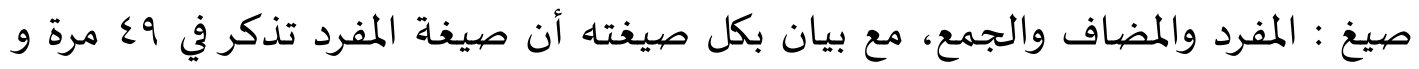

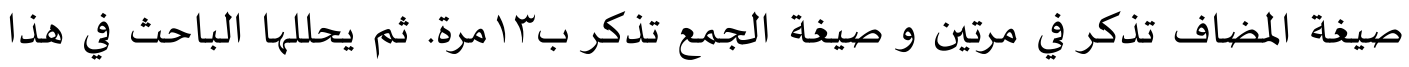

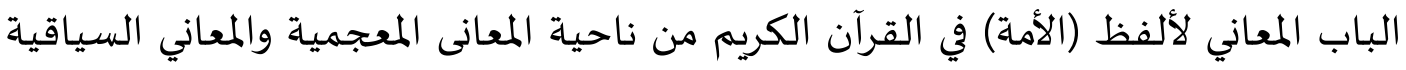

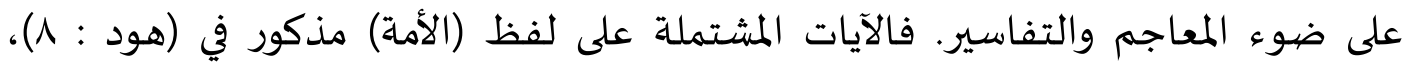

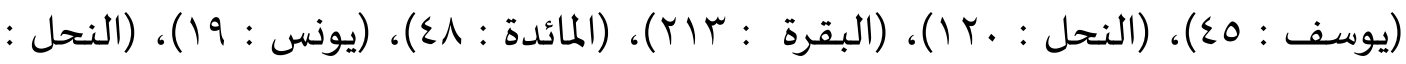

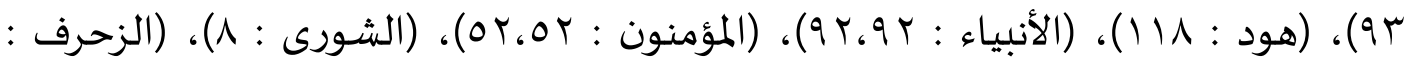
r

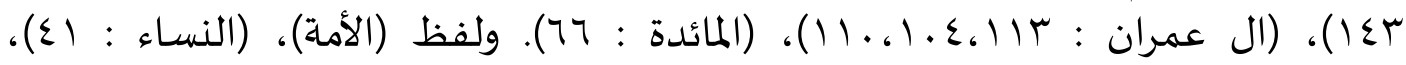

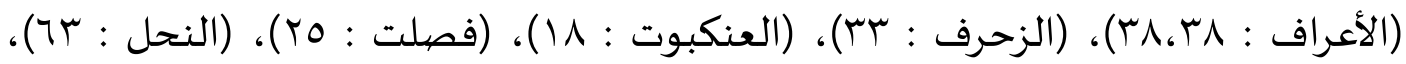

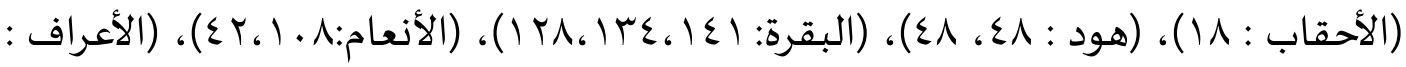

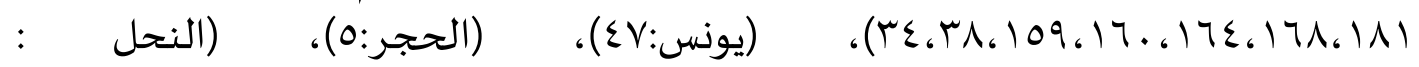
(الق ( 
Ta'Cim al-'Arabiyyah : Jumal Pendidikan Bahasa Arab dan Kebahasaaraban, 3 (2), 2019

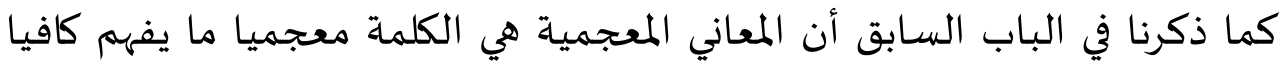

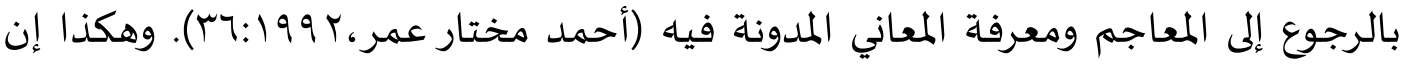

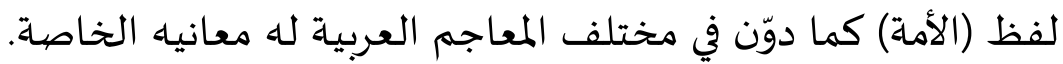

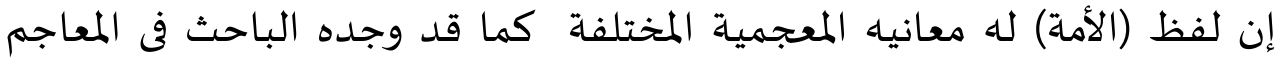

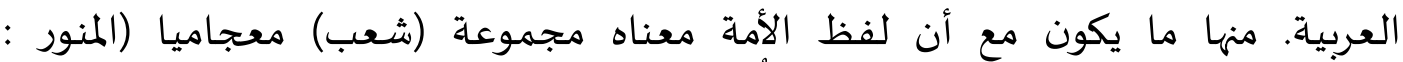

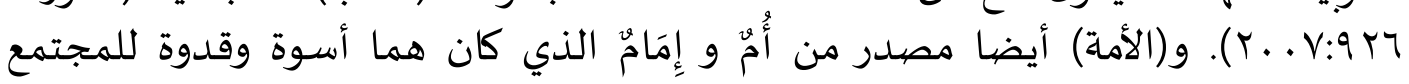

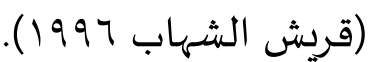

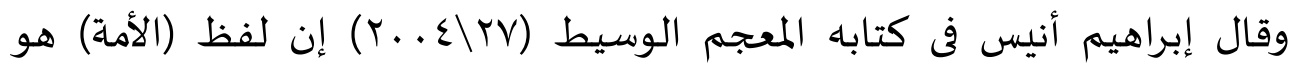

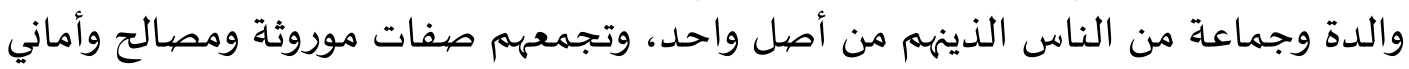

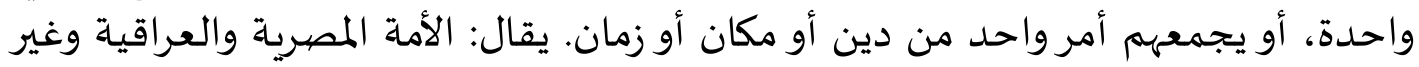
ذلك.

وقال الآخر إن لفظ (الأمة) هو الرجل الجامع لخصال الخير وفي الخي تنزيل العزيز.

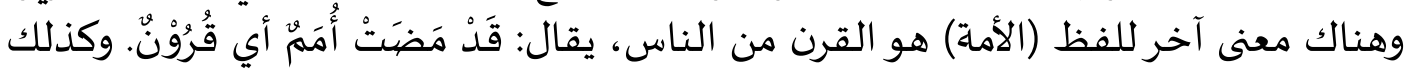

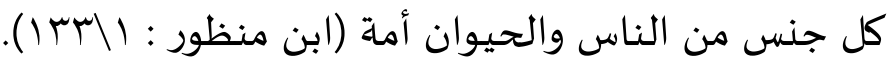

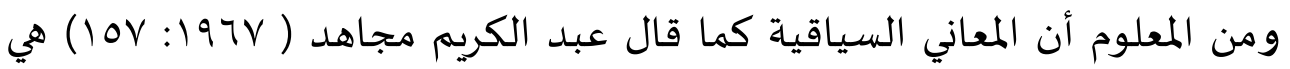

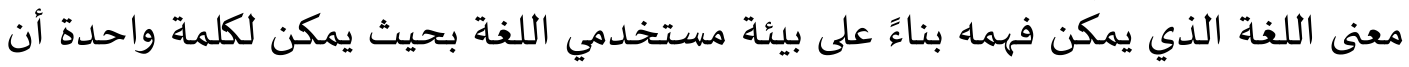

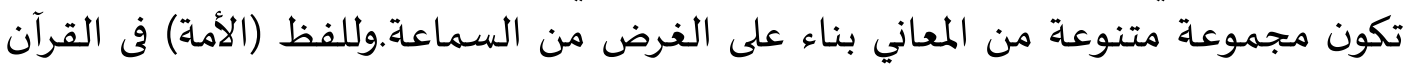

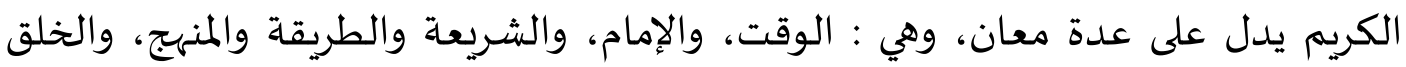

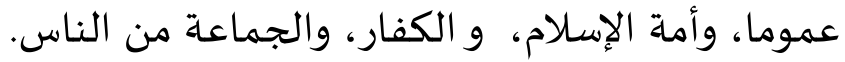

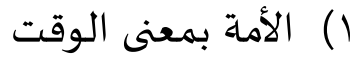

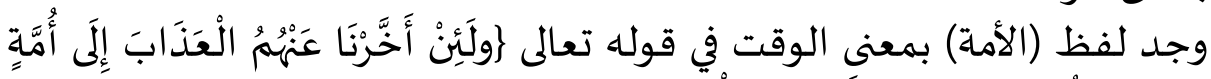

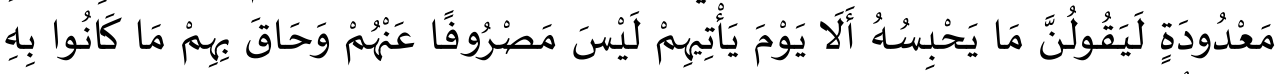

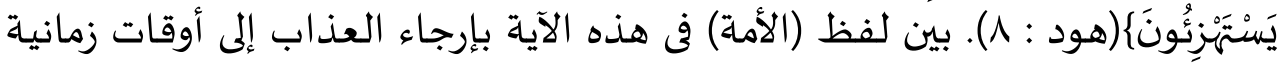

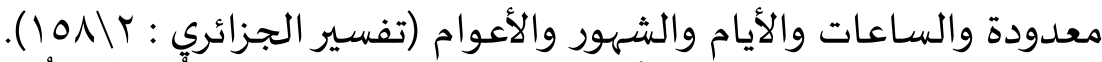

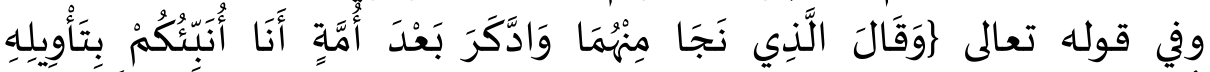

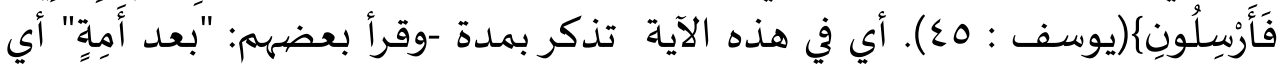

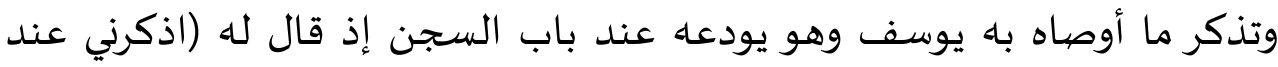

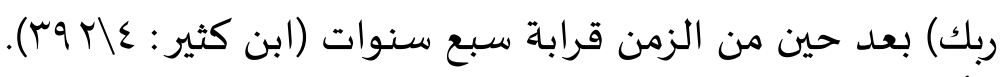

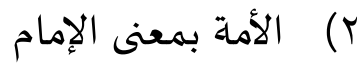

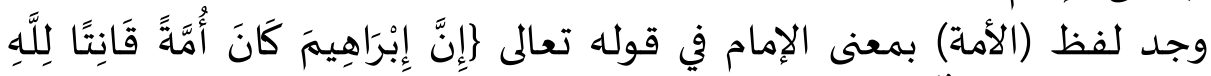

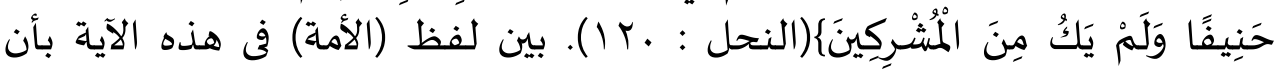

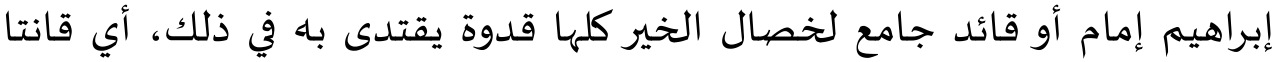

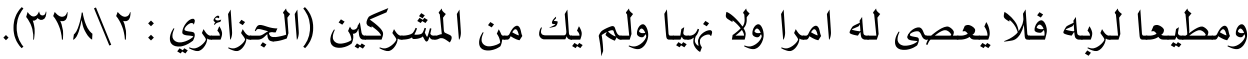


Ta'lim al-'Arabiyyah : Jurnal Pendidikan Bahasa Arab dan Kebahasaaraban, 3 (2), 2019

r) الأمة بمعنى الشريعة والطريقة والمنهج

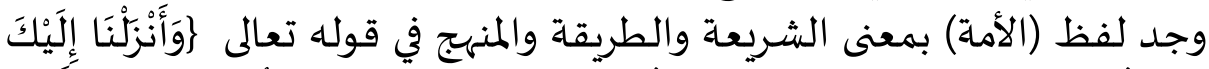

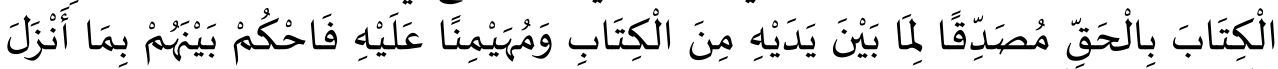

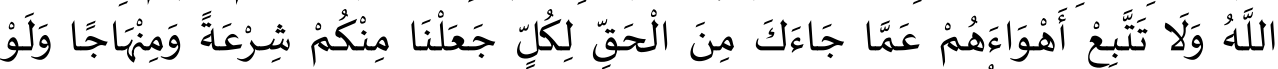

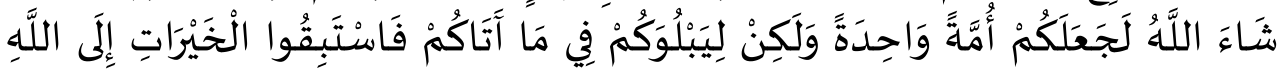

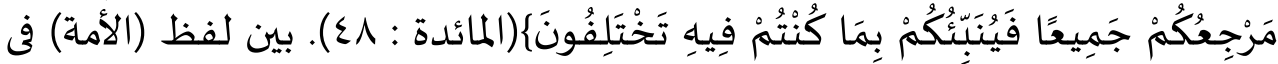

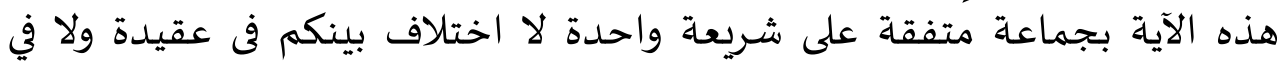

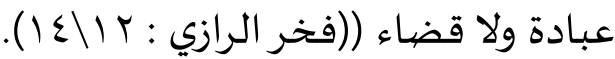

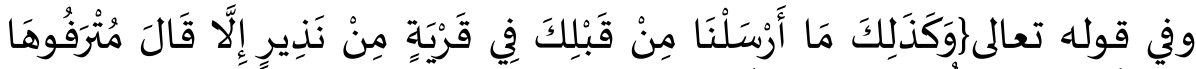

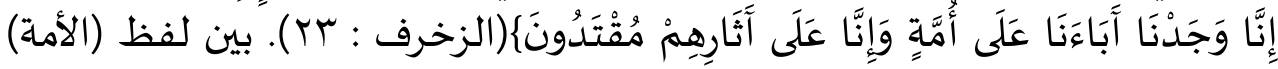

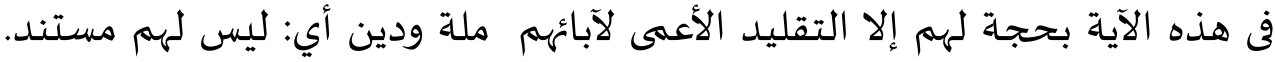

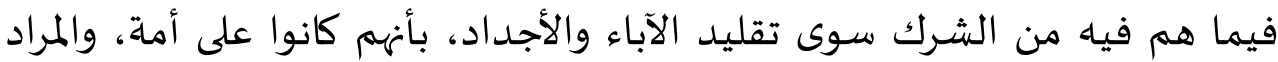

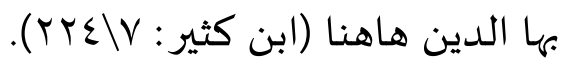

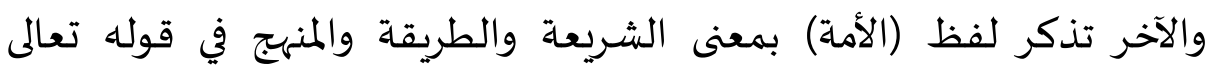

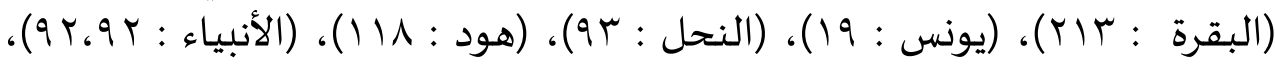

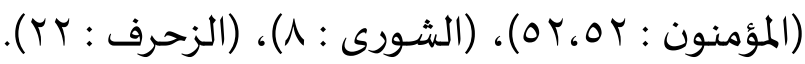

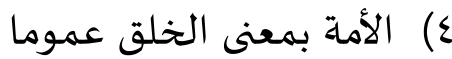

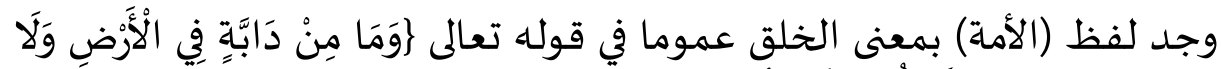

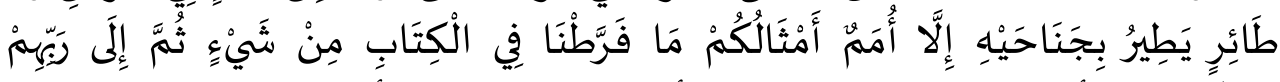

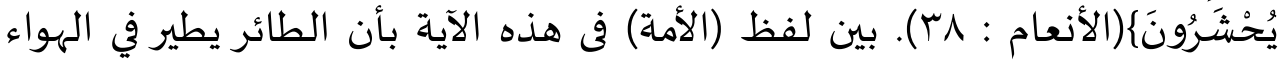

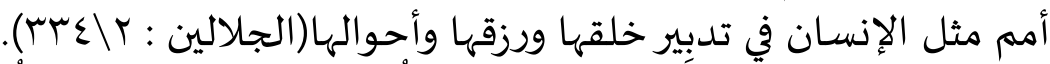

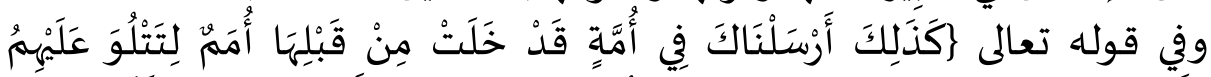

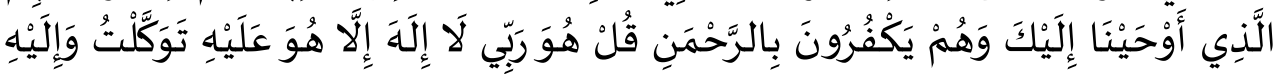

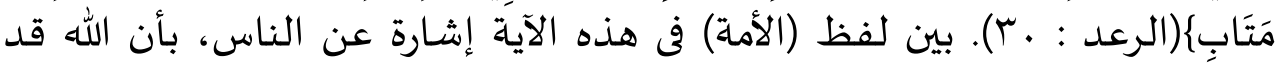

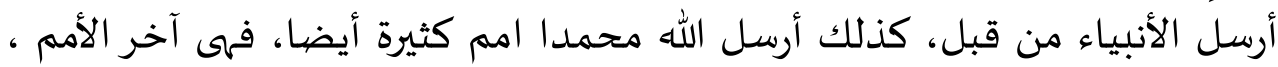

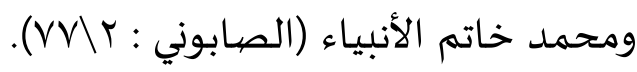

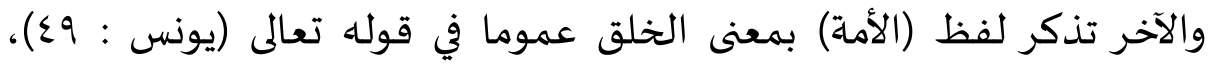

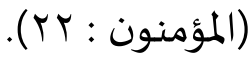

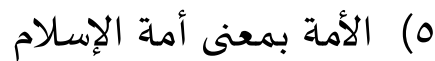

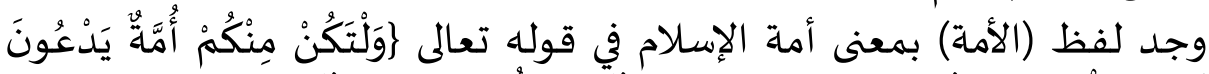

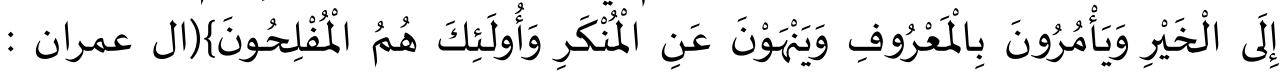

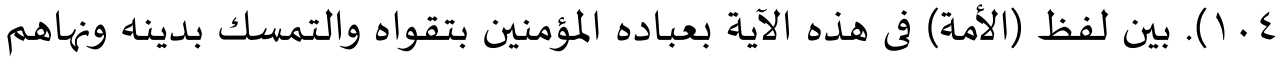


Ta'Cim al-'Arabiyyah : Jumal Pendidikan Bahasa Arab dan Kebahasaaraban, 3 (2), 2019

عن الفرقة والاختلاف وحضهم على ذكر نعماه ليشكروها بطاعته أمرهم في هذه

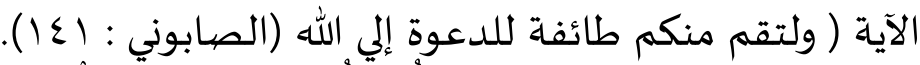

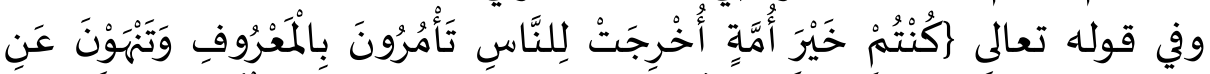

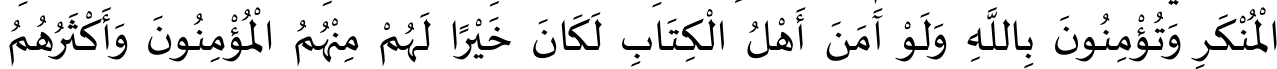

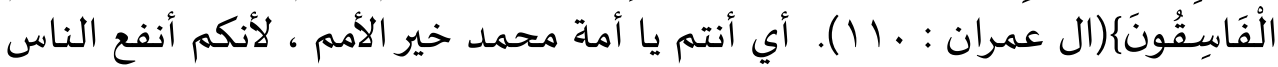

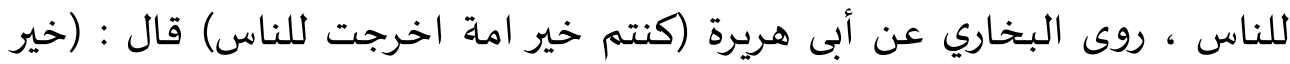

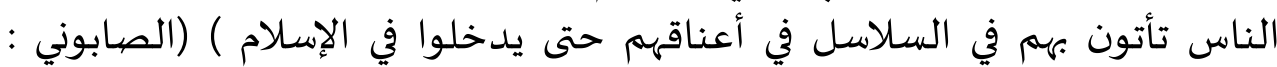

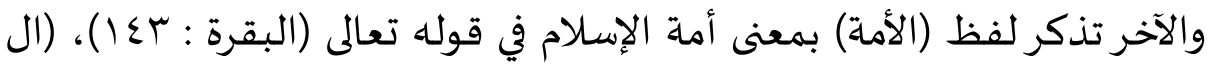

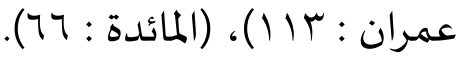

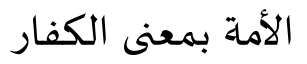

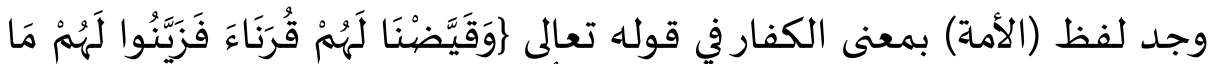

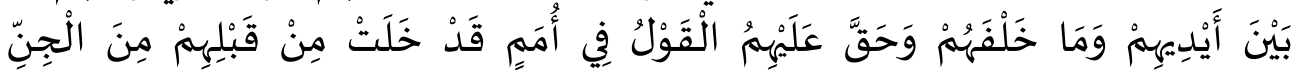

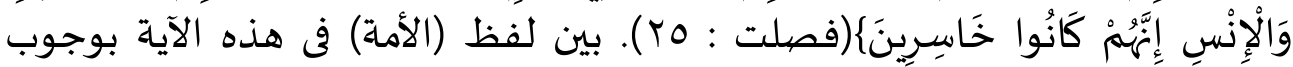

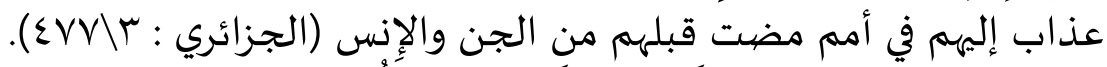

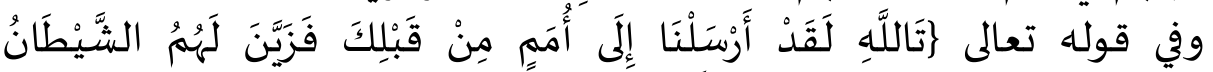

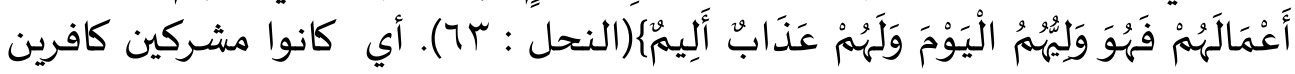

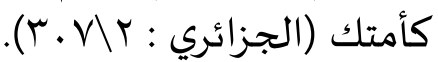

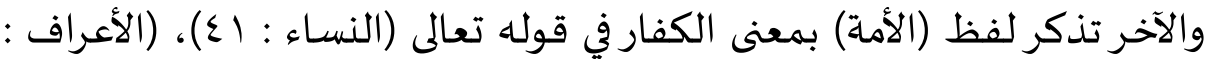

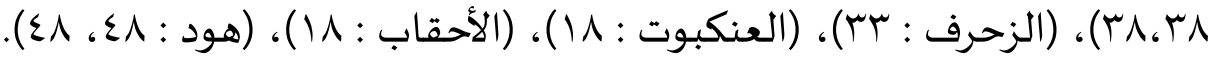

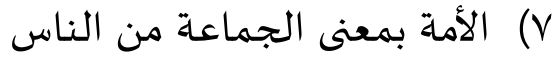

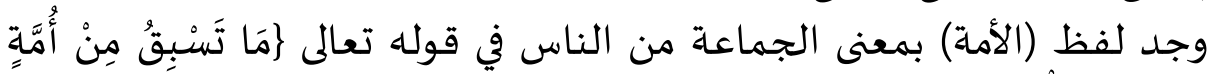

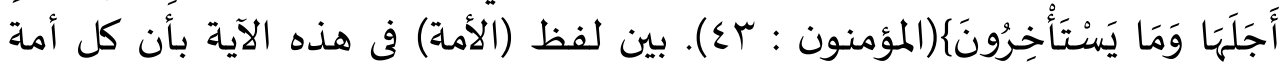

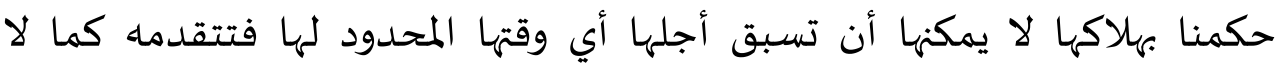

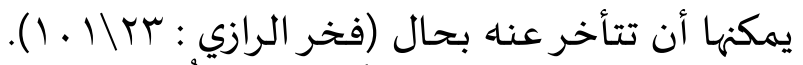

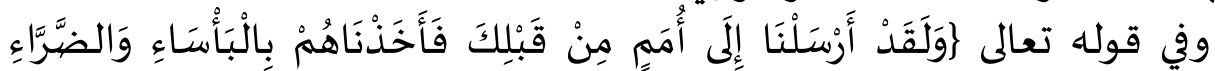

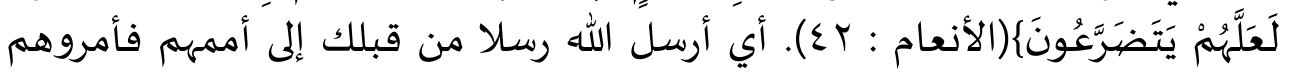

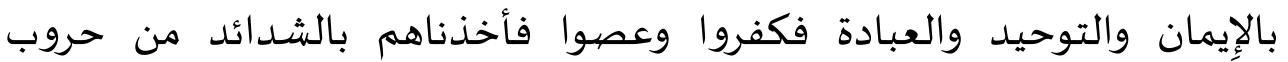

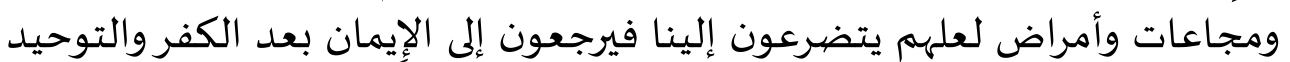

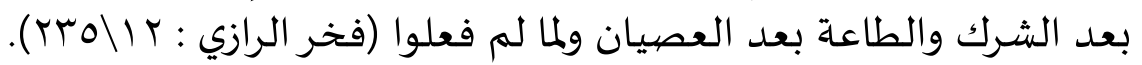

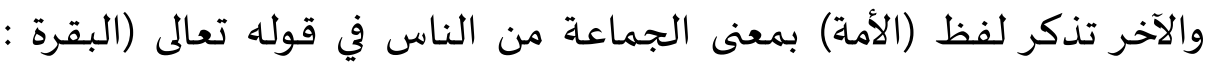

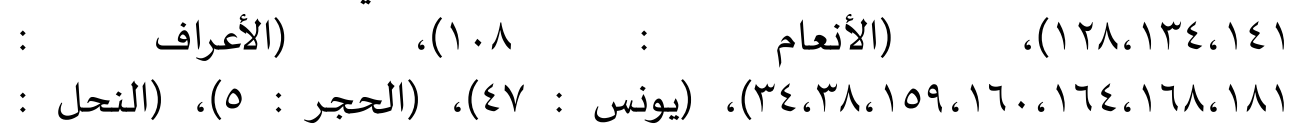


Ta'lim al-'Arabiyyah : Jurnal Pendidikan Bahasa Arab dan Kebahasaaraban, 3 (2), 2019

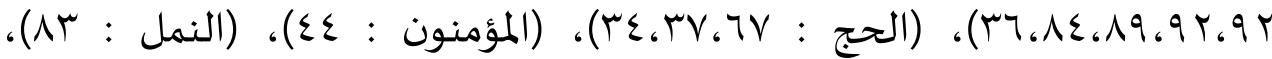

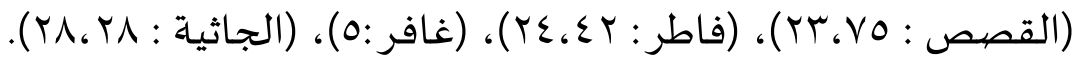

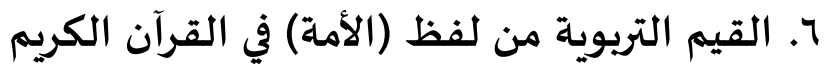

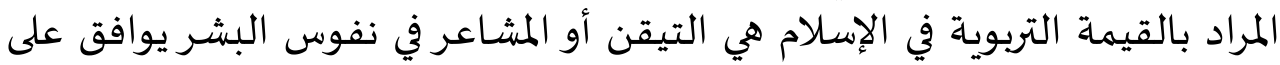

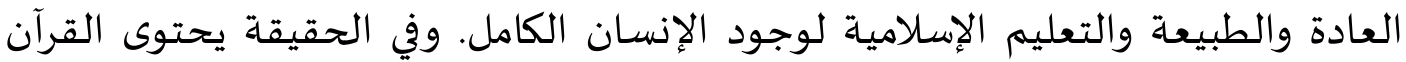

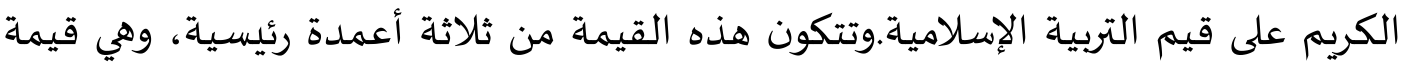

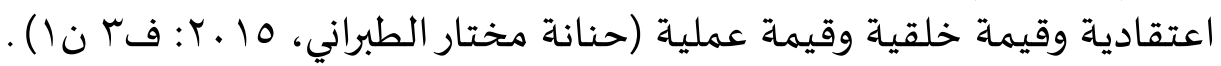

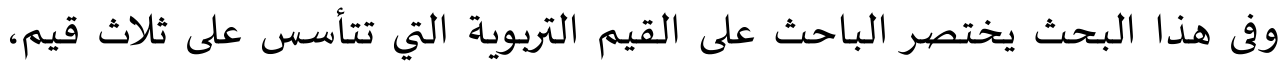
وهي قيم اعتقادية وقيم خلقية وقيم عملية من الآيات المشتملة على لفيم لفظ الفي (الأمة) في القرآن

\section{القيم الاعتقادية}

القيم الاعتقادية هي القيم التى ترتبط بتربية العقيدة كالإيمان بالله وملئكته الإنها

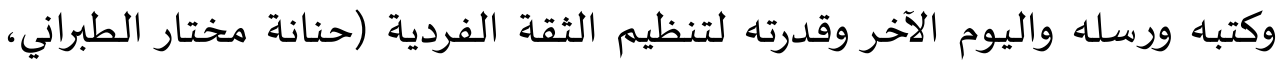

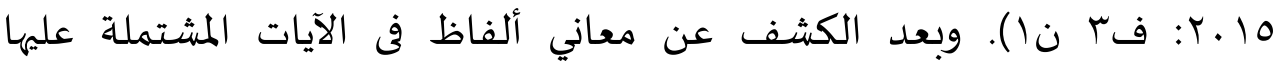

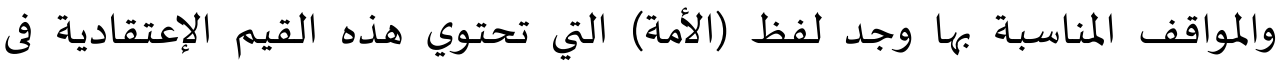

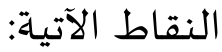

أ. توحيد الله تعالى والتيقن باه والتوكل عليه الاتيه

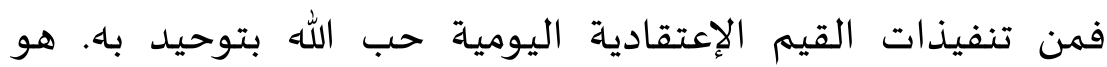

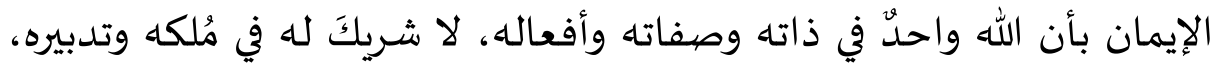

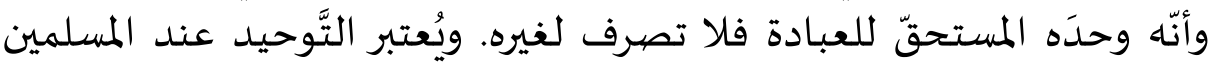

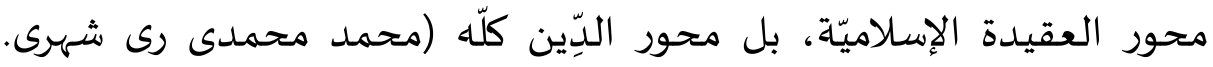
(.) : : Y...

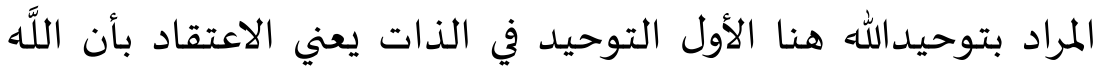

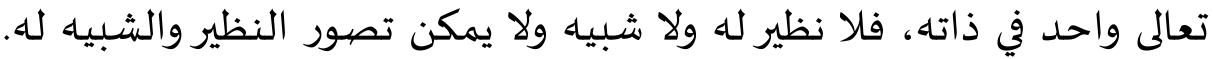

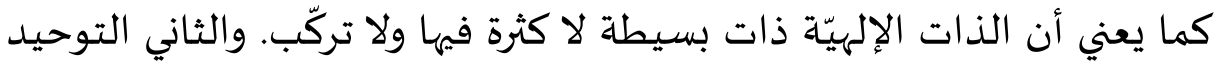

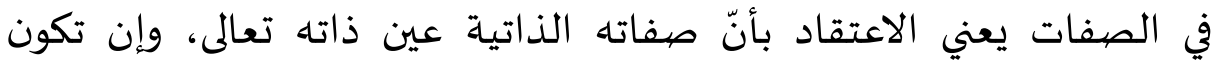

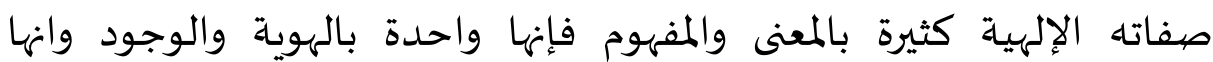

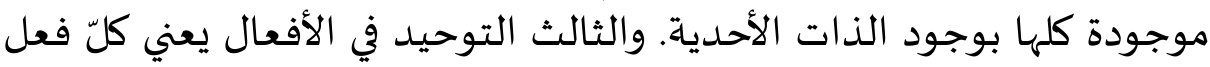

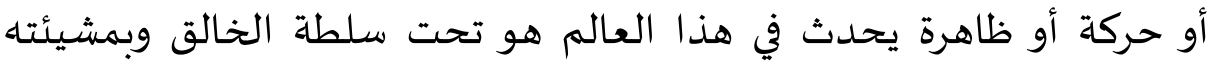

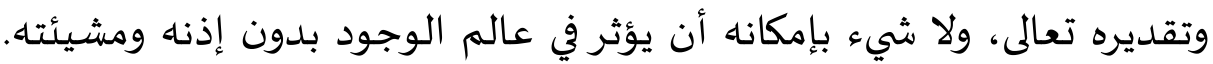

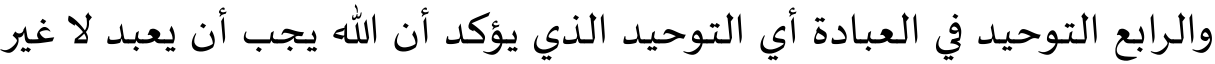

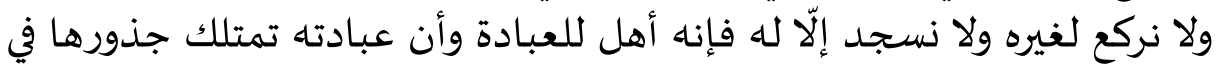


Ta'Cim al-'Arabiyyah : Jumal Pendidikan Bahasa Arab dan Kebahasaaraban, 3 (2), 2019

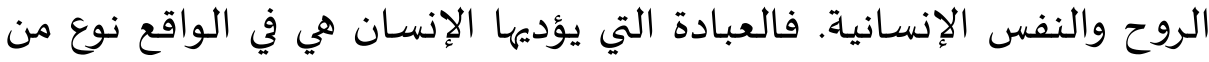

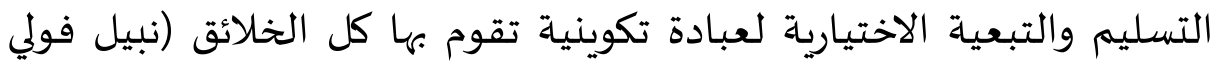

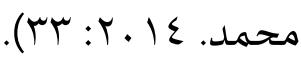

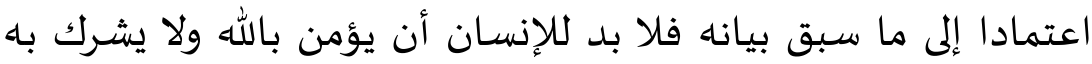

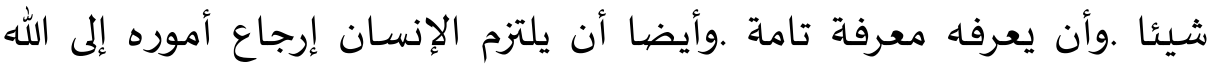

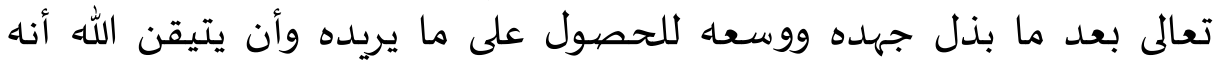

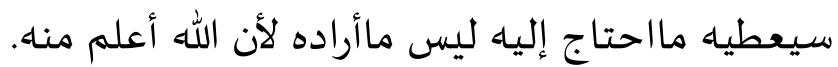

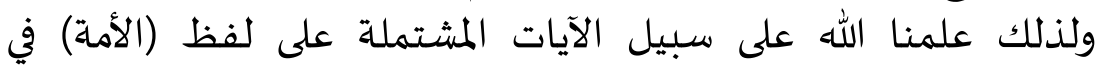

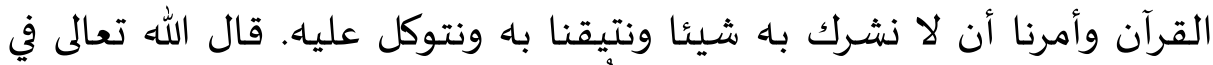

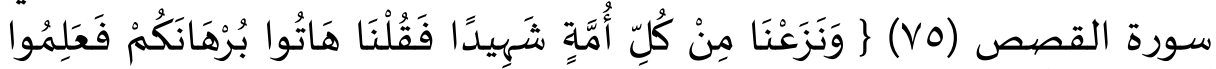

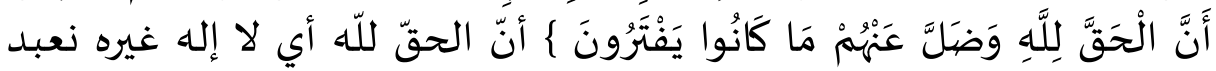

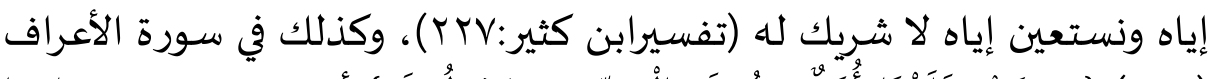

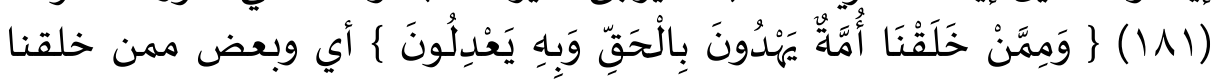

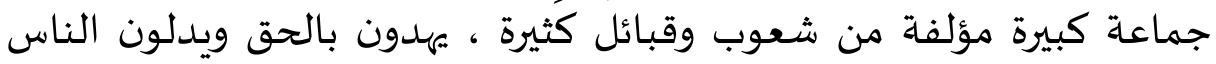

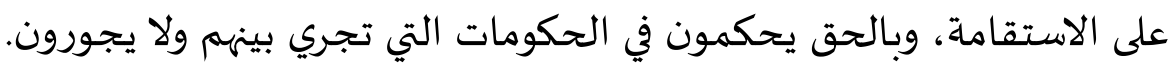

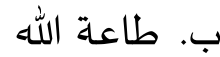

ومن تنفيذات القيم الاعتقادية طاعة الله ـ الطاعة هي فعل المأمورات

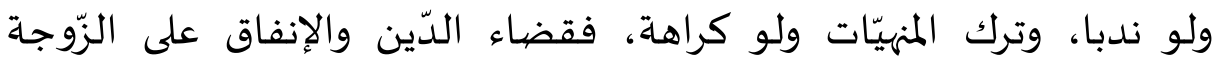

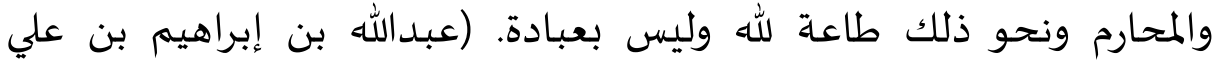
الطريقي. 1990: ع ـ (1) ).

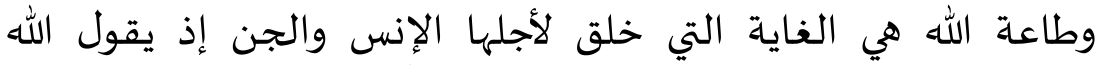

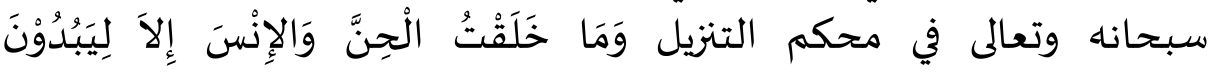

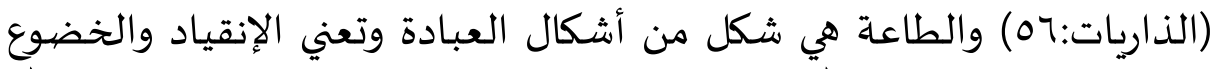

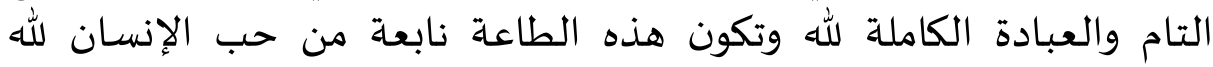

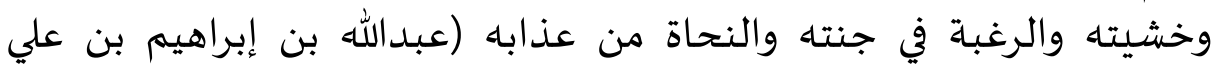

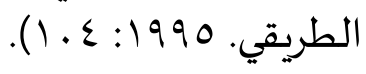

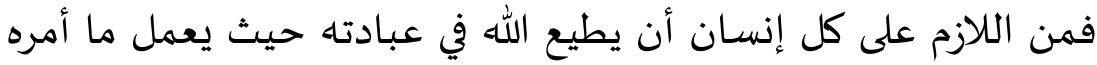

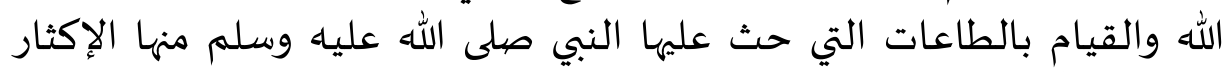

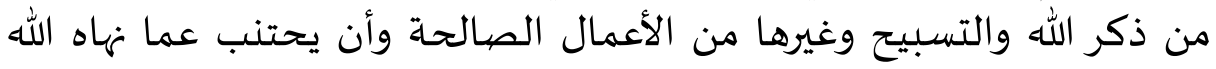

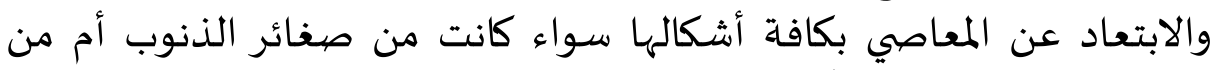

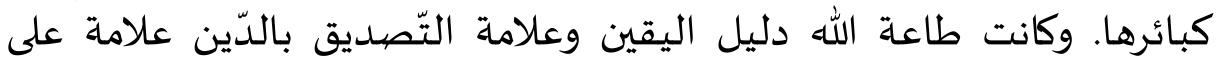

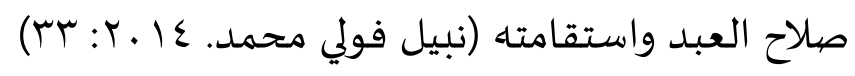


Ta'lim al-'Arabiyyah : Jurnal Pendidikan Bahasa Arab dan Kebahasaaraban, 3 (2), 2019

مما ينتج من البيان السابق أن القيم الإعتقادية مهمة في حياة الإنسان

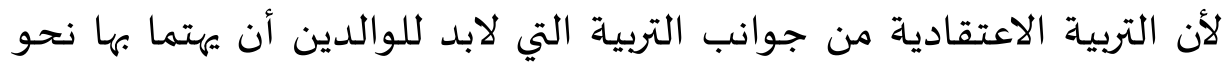

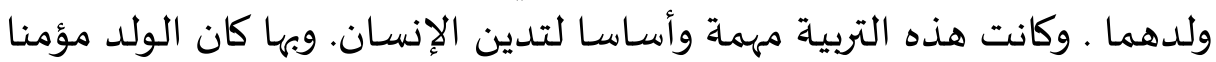
بالله ومطيعا باه ومجتتنبا من نواهياء.

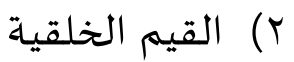

ويستنتج الباحث من هذا التعريف أن القيم الخلقية من أهم القيم التى لا لأئاء

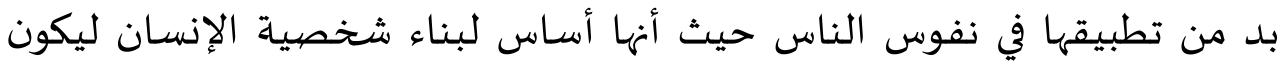

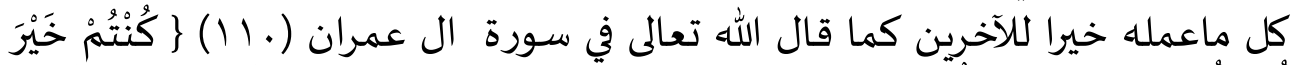

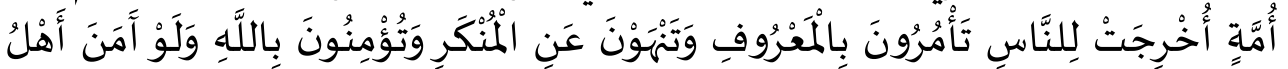

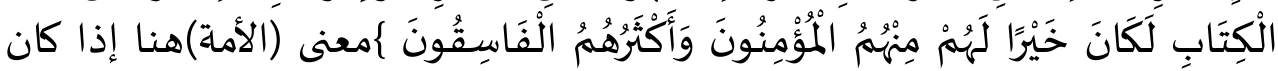

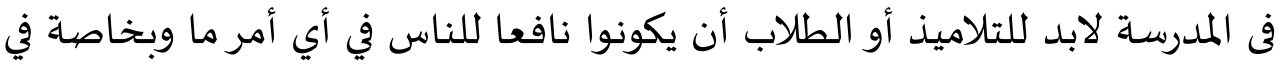

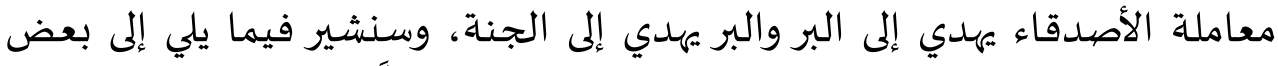

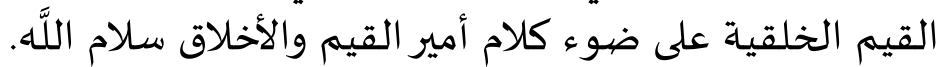

$$
\text { تتمثل هذه القيم الخلقية في النقاط الآتية: }
$$

الإنسان الناجح هو من يحسن استغلالال الوقت والفت ويعرف كيف يداير

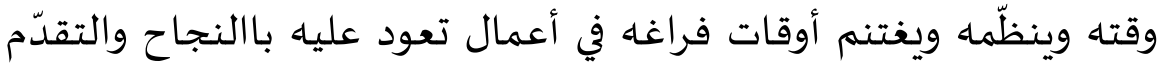

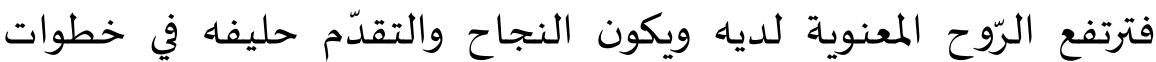

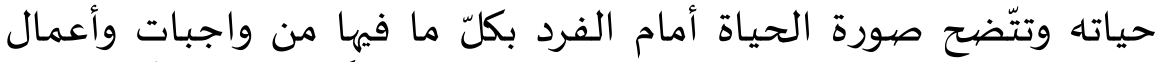

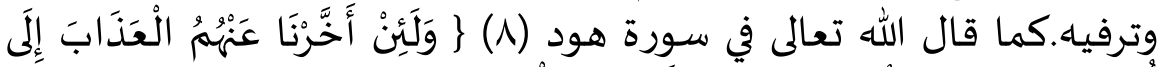

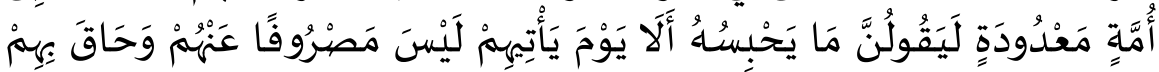

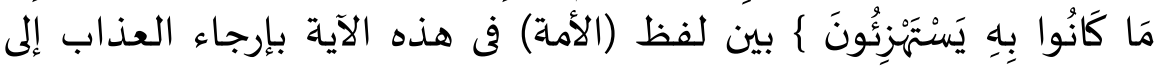

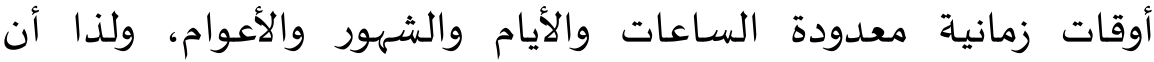

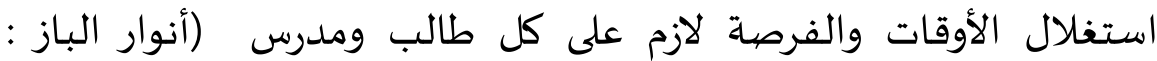
. (0.14

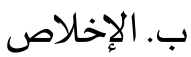

لقد خلق الله الخلق الجن والإنس لعبادته وحده لا شريك لله، وأمر

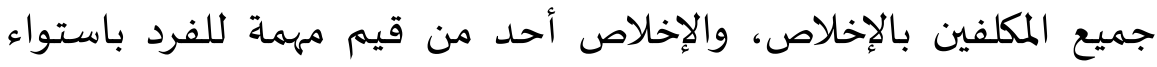

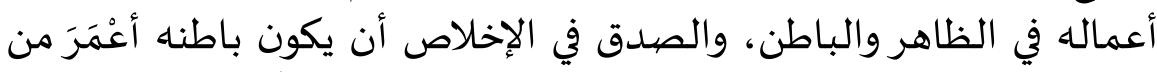

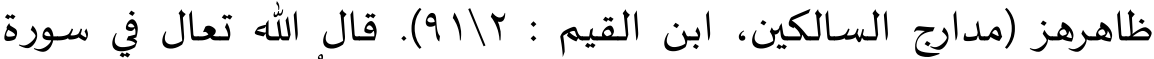

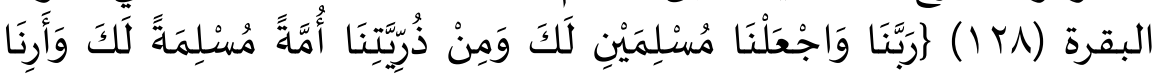


Ta'Cim al-'Arabiyyah : Jumal Pendidikan Bahasa Arab dan Kebahasaaraban, 3 (2), 2019

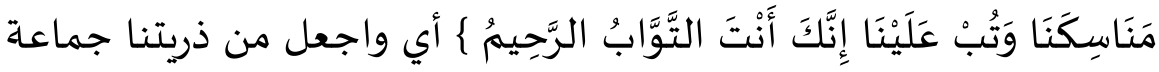

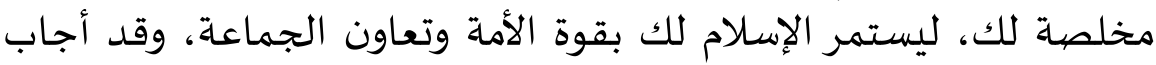

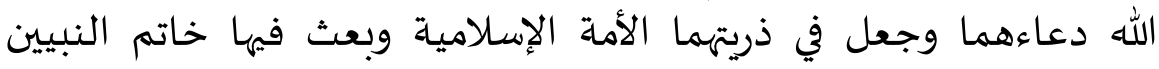

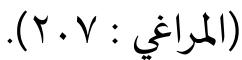

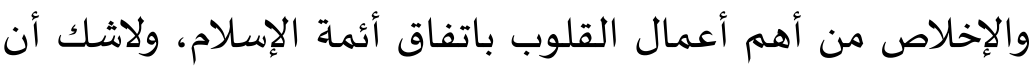

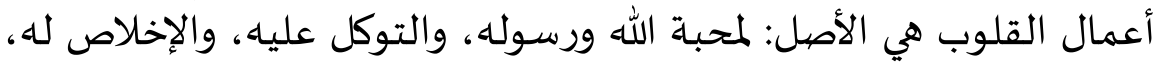

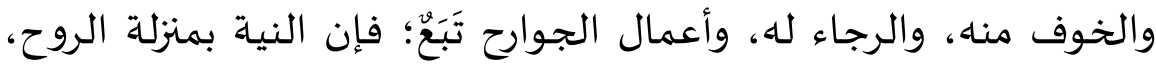

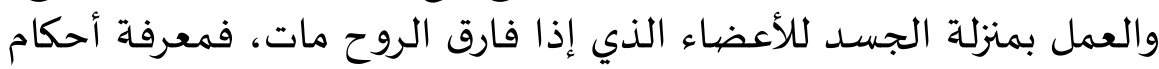

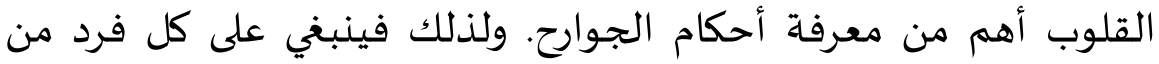

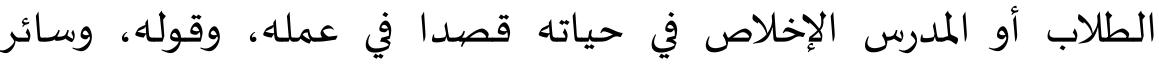

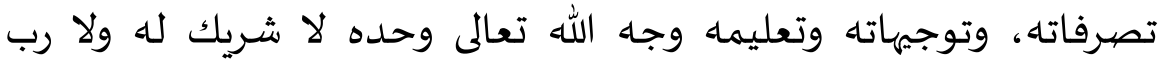

$$
\text { r) القيم العملية }
$$

فالإنسان هو الفرد الذي لا يعيش وحده في هذه الحياة، فهو بطبيعته

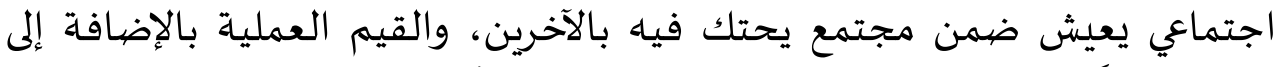

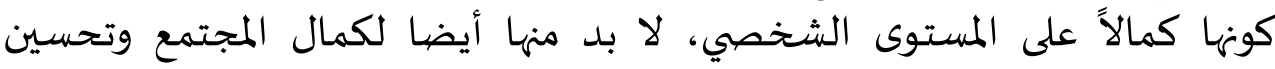

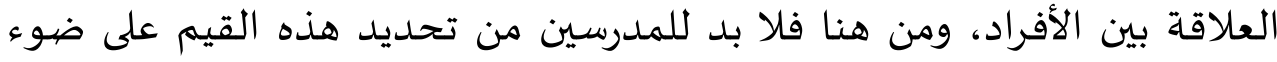

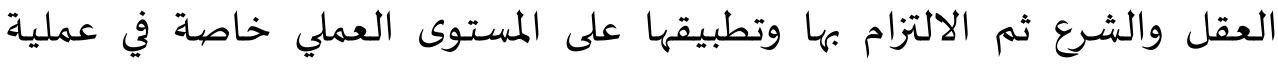

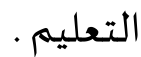

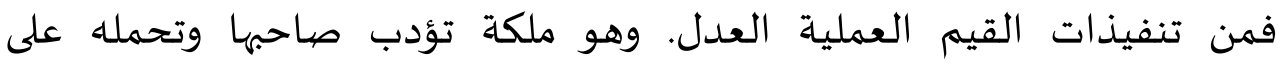

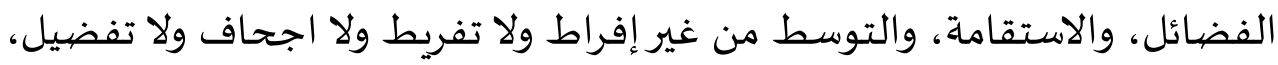

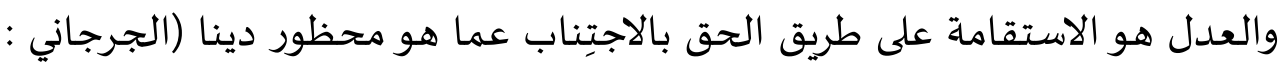

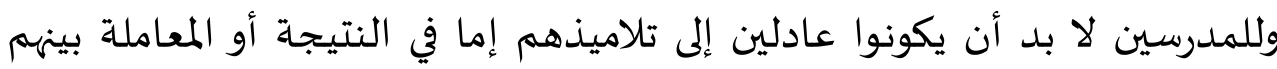

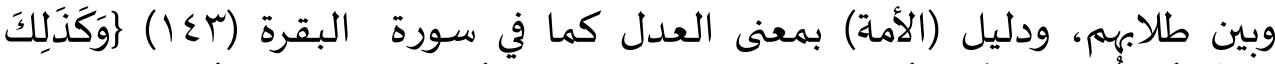

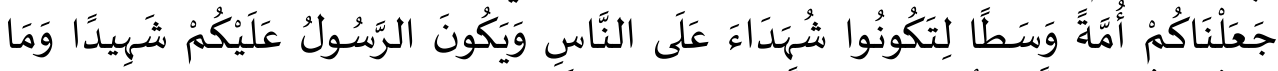

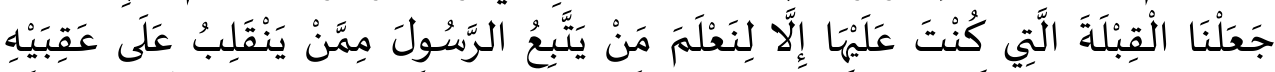

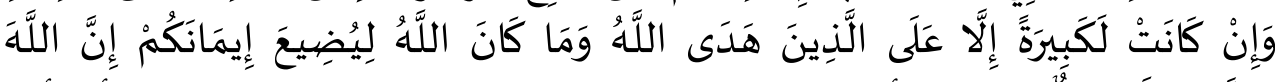

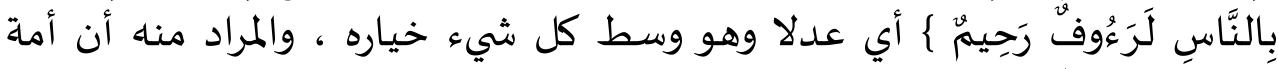

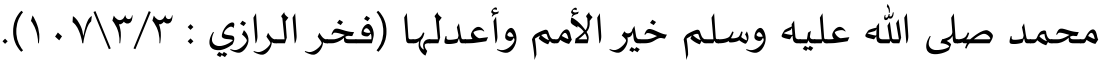


Ta'lim al-'Arabiyyah : Jurnal Pendidikan Bahasa Arab dan Kebahasaaraban, 3 (2), 2019

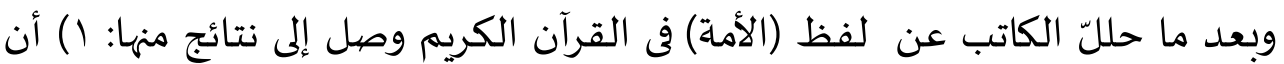

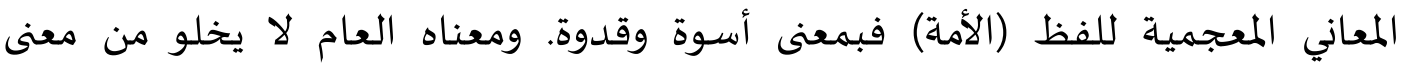

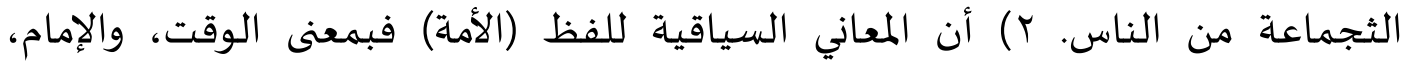

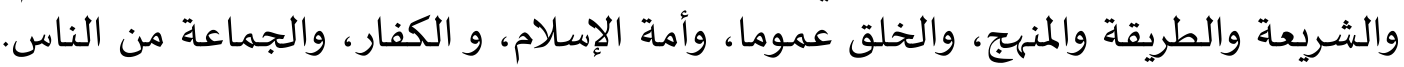

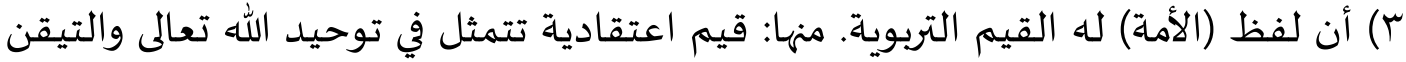

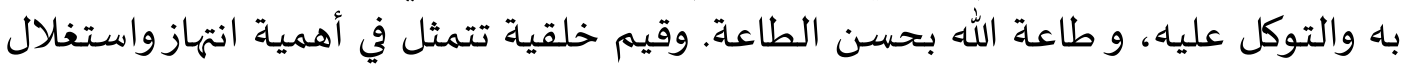

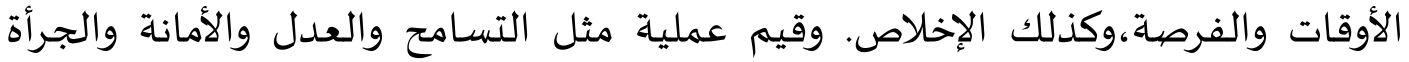

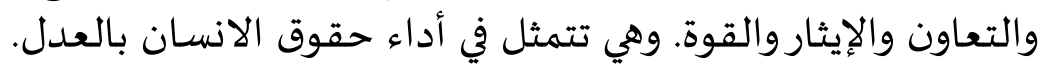

\section{المراجع}

Achmadi. 2008. Teologi Pendidikan Islam. Jakarta: Raja Grafindo Persada.

Al Banā, Hasan. 1992. Al Tarbiyah al Islamiyyah. Kairo: Dār al 'Arabiyyah lil Kutub.

Al Baq̄̄, Muhammad Fuad 'Abd. 1944. al Mu'jam al Mafabras li al Fādz al Qurān al Karim. Kairo: Dār al Hadīts.

Al Bāz, Anwār. 2007. Al Tafsìr al Tarbawiy lil Qurān al Karìm. Mesir: Dār al Nasyr lil Jāmi’àt.

Al Jazāirī, Abu Bakr. 1921. Aysaru al Tafāsìr. Beirut: Dār Fikr.

Al Marāghi. Ahmad bin Musthafā. 1946. Tafsìr al Marāghi. Mesir: Sirkah Maktabah al 'Arabiyyah wa Muthaba'ah.

Al Qathān. 1973. Mabāhits fì 'Ulūm al Qurān. Beirut: Mansyūrah al 'Ashr Hadīts.

Al Rāzi, Fakhru al Dīn. 1990. Mafātīh al Ghayb. Beirut: Dār Fikr.

Al Shabun̄i, Muhammad Ali. 1999. Shafwatu al Tafāsīr. Beirut: Dār Fikr.

Arikunto, Suharsimi. 2002. Prosedur Penelitian Suatu Pendekatan Praktek. Jakarta: Rineka Cipta .

Bisri, Cik Hasan. 1998. Penuntun Penyusunan Rencana Penelitian dan Penulisan Skripsi. Jakarta: Logos.

Chaer, Abdul. 2002. Pengantar Semantik Bahasa Indonesia. Jakarta: Rineka Cipta.

Gunawan, Heri. 2017. Dasar-Dasar Metodelogi Penelitian Pendidikan. Bandung: PBA UIN SGD Bandung. 
Ta'lim al-'Arabiyyah : Jumal Pendidikan Bahasa Arab dan Kebahasaaraban, 3 (2), 2019

Mandzūr, Ibn. 1991. Lisān al 'Arabi. Beirut: Dār al Shādir.

Santi, Lisnawati, dkk. 2013. Penelitian Kualitatif Pendidikan Agama Islam. Bandung: Remaja Rosda Karya.

Shihab, Muhammad Quraish. 1998. Mukjizat Al-Quran. Bandung: Mizan.

Sugiyono. 2007. Metode Penelitian Pendidikan. Bandung: Alfabeta. 